\title{
Langattomien laitteiden käyttäminen maatilaolosuhteissa
}

\author{
Johannes Tiusanen ${ }^{1), 2)}$ \\ ${ }^{1)}$ Helsingin yliopisto, Agroteknologian laitos, PL28,00014, johannes.tiusanen@helsinki.fi \\ ${ }^{2)}$ T:mi Kuokka-keksinnöt, Suosmerentie 200, 28450 Vanha-Ulvila
}

\section{Tiivistelmä}

Radiojärjestelmän suorituskyky riippuu sekä laitevalinnasta että laitteiden asianmukaisesta käyttämisestä. Radioaallon etenemisen ja antennien toimintaperiaatteiden ymmärtäminen auttaa käyttäjää valitsemaan tarkoituksiinsa sopivimmat laitteet ja käyttämällä niitä oikein. Tässä esityksessä annetaan yleiskuva edellä mainituista silmälläpitäen maatalousympäristöä. Yksittäisten toimintavinkkien antamisen sijaan esityksessä selitetään radioaaltoon ja -laitteisiin liittyviä mekanismeja.

Kaikki radioaallon sähkökentässä tapahtuvat ilmiöt vaikuttavat signaalin tehoon toisessa potenssissa. Miten paljon radioaalto vaimenee vapaassa tilassa, riippuu etäisyydestä. Vaimennus on jyrkkä lähellä lähdettä, mutta alkaa muistuttaa lineaarisesti vaimenevaa tasoaaltoa kauempana. Sähkökenttään osuvat kiinteät kappaleet vaikuttavat aaltoliikkeeseen ja häiritsevät radioaallon etenemistä. Lähellä antennia sijaitsevan materiaalin vaikutus on sitä voimakkaampi, mitä suurempi on materiaalin permittiivisyys. Yleensä heijastumiset aiheuttavat merkittävimmät vaimennukset, mutta myös materiaalin läpi kulkeva radioaalto vaimenee. Heijastuminen aiheuttaa myös monitie-etenemistä.

Lähettimen lähetysteho on määräyksin rajattu pääosin tehoille 1, 10 tai $25 \mathrm{~mW}$. Vastaanottimen tärkeimmät ominaisuudet ovat herkkyys ja signaali-kohina-suhde. Suuresta herkkyydestä ei ole hyötyä jos taustakohina on voimakasta, sillä signaali jää kohinan peittoon. Kun tunnetaan lähettimen teho ja vastaanottimen herkkyys tai kohinateho, voidaan laskea häipymävara (dB).

Kun antenni on vireessä, muodostuu antennin ympärille seisova aaltoliike ja antenni säteilee. Jos antennin välittömässä läheisyydessä on esineitä, antennin hyötysuhde romahtaa. Antennin vahvistus perustuu suuntaavuuteen, eli vahvistus yhdellä suunnalla aiheuttaa vaimennusta toisaalla.

\section{Johdanto}

Matkapuhelimien ja paikannuslaitteiden rinnalla ovat muihinkin radiotekniikoihin perustuvat laitteet alkaneet yleistyä maatilaympäristössä ja tutkimuslaitteistoissa. Yhä useammin elektroniset laitteet kommunikoivat keskenään langattomasti. Jatkuvatoimisten laitteiden valvontajärjestelmät ovat paljolti langattomia. Mittalaitteiden langaton tiedonkeruu mahdollistaa yhtäältä jonkin prosessin sisäisten parametrien mittaamisen, toisaalta keskitetyn tiedonkeruun pitkien etäisyyksien yli. Yleisimpiä tekniikoita matkapuhelinverkon rinnalla ovat WLAN, BlueTooth ja RF-ID, jotka toimivat ns. lisenssivapailla ISM-taajuuksilla (Industry, Science and Medical) 433, 868, 2400 ja 5700 MHz. Näillä taajuuksilla toimivat myös lukuisat standardoimattomia protokollia käyttävät itkuhälyttimet, videokamerat, pihalämpömittarit jne. Radiojärjestelmän suorituskyky riippuu sekä tarkoituksenmukaisesta laitevalinnasta että laitteiden asianmukaisesta käyttämisestä.

Laitteiden teknisissä tiedoissa ilmoitetaan usein vain kantoetäisyys, toisinaan myös käytettävä radiotaajuus tai protokolla. Radioaallon etenemisen ja antennien toimintaperiaatteiden ymmärtäminen auttaa käyttäjää valitsemaan tarkoituksiinsa sopivimmat laitteet ja käyttämällä niitä oikein parantamaan sekä tiedonsiirron laatua että tehoa. Tässä esityksessä annetaan yleiskuva edellä mainituista silmälläpitäen maatalousympäristöä. Yksittäisten toimintavinkkien antamisen sijaan esityksessä selitetään radioaaltoon ja -laitteisiin liittyviä mekanismeja sillä tarkkuudella kuin langattomien laitteiden käyttäjän on hyvä niitä tuntea.

\section{Radioaalto}

Radioaallolla tarkoitetaan sähkömagneettista aaltoliikettä, jonka aallonpituus on $1 \mathrm{~mm}-10.000 \mathrm{~km}$. Sähkökentän voimakkuus mitataan yksikössä Volttia/metri. Radiosignaalien yhteydessä puhutaan kuitenkin yleisimmin tehosta, jonka yksikkö on Watti. Sähkömagneettisen kentän tehotiheys S riippuu jännitteestä toisessa potenssissa $\left(S=U^{2} / Z_{0}\right)$. Tästä seuraa, että myös kaikki radioaallon sähkökentässä tapahtuvat ilmiöt vaikuttavat signaalin tehoon toisessa potenssissa. Yleisin radiolaitteiden tehoyksikkö on milliwatti $\mathrm{mW}$ tai yhden $\mathrm{mW}: n$ desibeli, joka merkitään $\mathrm{dBm}$ (esim. $+20 \mathrm{dBm}=100 \mathrm{~mW}$ ja $20 \mathrm{dBm}=0,01 \mathrm{~mW})$. 


\section{Vapaan tilan vaimennus}

Se, miten paljon radioaalto vaimenee vapaassa tilassa (tyhjiössä tai ilmassa) riippuu etäisyydestä. Kun radioaallon lähde on pistemäinen, leviää radioaalto kasvavan pallon pinnan muotoisesti kaikkiin suuntiin lähteestä, eli sähkökentän tehotiheys alenee logaritmisesti. Siksi vaimennus on jyrkkä lähellä lähdettä, mutta mitä kauemmas lähteestä aalto etenee, sitä enemmän se alkaa muistuttaa tasoaaltoa joka vaimenee lineaarisesti.

Vapaan tilan vaimennus riippuu myös aallonpituudesta siksi, että oletetulla vastaanottoantennilla on tietty tehollinen sieppauspinta-ala $A_{\text {eff }}$, joka on verrannollinen aallonpituuteen. Voidaan ajatella, että esimerkiksi yhden aallonpituuden mittainen antenni "pyydystää" aaltotehoa pyörähdysympyränsä kokoisen ikkunan alalta. Käytettäessä edelliseen nähden puolikasta taajuutta eli kaksinkertaista aallonpituutta, on antennin pituuskin kaksinkertainen ja pyörähdysympyrän pinta-ala nelinkertainen, jolloin antennin sieppausalalta kytkeytyy myös nelinkertainen aaltoteho.

Pallomaisesti kasvavan etäisyyden ja antennin sieppauspinta-alan vaikutukset yhdistyvät laskettaessa vapaan tilan vaimennus Friisin yhtälöllä:

$$
L=10 \times \log _{10}\left((4 \pi d)^{2} / \lambda^{2}\right)=20 \times \log _{10}(4 \pi d / \lambda)
$$

jossa $L$ on vaimennus [dB], $d$ on lähettimen ja vastaanottimen etäisyys [m] ja $\lambda$ aallonpituus [m]. Taulukkoon 1 on laskettu vaimennuksia tyypillisimmillä ISM-taajuuksilla eri etäisyyksillä. Edellä mainitut ilmiöt on helppo havaita: etäisyyden kasvattaminen kymmenkertaiseksi (esim. $10 \mathrm{~m} \rightarrow 100$ m) kasvaa vaimennus $20 \mathrm{~dB}$ eli satakertaiseksi. Vaihdettaessa kaksinkertaiselle taajuudelle (435 $\mathrm{MHz}$ $\rightarrow 870 \mathrm{MHz}$ ) kasvaa vaimennus $6 \mathrm{~dB}$ eli nelinkertaiseksi.

Taulukko 1. Vapaan tilan vaimennus [dB] eri etäisyyksillä ja taajuuksilla.

\begin{tabular}{lrrrrrrrrrr} 
& \multicolumn{10}{c}{ Etäisyys } \\
\cline { 2 - 12 } Taajuus & $1 \mathrm{~m}$ & $2 \mathrm{~m}$ & $5 \mathrm{~m}$ & $10 \mathrm{~m}$ & $20 \mathrm{~m}$ & $50 \mathrm{~m}$ & $100 \mathrm{~m}$ & $200 \mathrm{~m}$ & $500 \mathrm{~m}$ & $1000 \mathrm{~m}$ \\
\hline $435 \mathrm{MHz}$ & 25 & 31 & 39 & 45 & 51 & 59 & 65 & 71 & 79 & 85 \\
$870 \mathrm{MHz}$ & 31 & 37 & 45 & 51 & 57 & 65 & 71 & 77 & 85 & 91 \\
$2400 \mathrm{MHz}$ & 40 & 46 & 54 & 60 & 66 & 74 & 80 & 86 & 94 & 100 \\
\hline
\end{tabular}

\section{Esteistä ja rajapinnoista}

Ilmaa voidaan pitää häviöttömänä väliaineena. Sen sijaan sähkökenttään osuvat kiinteät kappaleet vaikuttavat aaltoliikkeeseen. Itse asiassa esteet, jotka ovat lähelläkin radiolaitteiden suoraa näköyhteyttä, sijaitsevat nk. Fresnelin ellipsoidin sisällä ja häiritsevät radioaallon etenemistä. Fresnelin ellipsoidin sisään osuvan kappaleen estevaimennus voi olla 0-20 dB, eli linjalle osuva kukkulan huippu voi pudottaa järjestelmän kantavuuden jopa kymmenesosaansa.

Lähellä antennia sijaitsevan materiaalin vaikutus on sitä voimakkaampi, mitä suurempi on materiaalin permittiivisyys. Yleisimmin permittiivisyys ilmoitetaan suhteellisena permittiivisyytenä $\varepsilon_{r}$, joka kertoo kuinka moninkertainen väliaineen permittiivisyys on verrattuna tyhjiöön (luonnonvakioon $\varepsilon_{0}$ ). Taulukkoon 2 on kerätty muutaman maatilaolosuhteissa tyypillisen materiaalin $\varepsilon_{r}$ eri lähteistä. Kahden eri väliaineen $\varepsilon_{r}$ suhdelukua kutsutaan taittokertoimeksi $\varepsilon_{2} / \varepsilon_{l}$, joka myös kertoo rajapinnalta tapahtuvan heijastuksen voimakkuuden. Tästä syystä materiaalit, jotka poikkeavat suuresti ilman permittiivisyydestä $\left(\varepsilon_{r}=1\right)$, häiritsevät radioaallon etenemistä eniten. Yleensä heijastumiset aiheuttavat merkittävimmät vaimennukset, mutta $\varepsilon_{r}$ on suuntaa-antava myös silloin kun arvioidaan, paljonko materiaalin läpi kulkeva radioaalto vaimenee.

Taulukko 2. Eräiden materiaalien suhteellisia permittiivisyyksiä noin $1 \mathrm{GHz}$ taajuudella.

\begin{tabular}{llll} 
Materiaali & $\varepsilon_{r}$ & Materiaali & $\varepsilon_{r}$ \\
\hline Vesi & 80 & Betoni & 4 \\
Jää & 3 & Uunikuiva multa & 3 \\
Lasi & $4-10$ & Kostea multa & $10-20$ \\
Kuiva puu & $3-7$ & Märkä multa & $25-40$ \\
\hline
\end{tabular}


Radioaallon heijastumisella on myös signaalin kulun estämisen lisäksi toinenkin vaikutus, jota kutsutaan monitie-etenemiseksi. Tällöin yhden radioaallon kulkiessa suorinta reittiä antennilta toiselle, kulkee yksi tai useampi säde pitemmän reitin jonkin heijastavan pinnan kautta. Heijastunut aalto saavuttaa vastaanottimen enemmän tai vähemmän myöhästyneenä ja aaltojen summana muodostuu vääristynyt aalto. Mitä heikompi heijastunut aalto on (mitä alhaisempi heijastuspinnan $\varepsilon_{r}$ ), sitä vähemmän signaali vääristyy. Toisaalta eräissä tilanteissa on mahdollista, että heijastusreitti on täsmälleen yhden tai kaksi aallonpituutta suoraa reittiä pitempi, jolloin suoraan kulkeva ja heijastunut aalto summautuvat alkuperäistä voimakkaammaksi aalloksi ja signaalin teho paranee. Näin tapahtuu esim. silloin, kun antennit ovat sopivalla korkeudella ja osa aallosta heijastuu maanpinnan kautta.

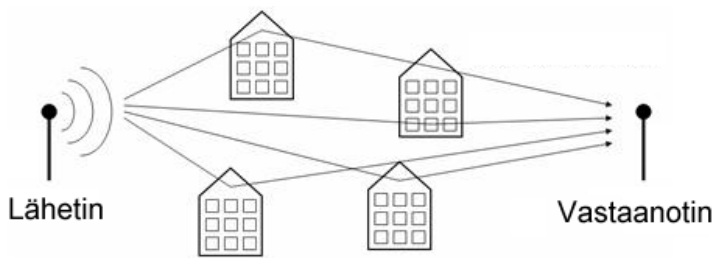

Kuva 1. Monitie-eteneminen, kun radioaallot heijastuvat rakennuksista.

Aivan oma asiakokonaisuutensa on diffraktio, jota tapahtuu terävien kulmien kohdalla. Tyypillisin esimerkki on diffraktiovaimennus kulman taakse, esimerkiksi jos kivitalon nurkka sijaitsee suoran näköyhteyden tiellä. Aalto voi diffraktoitua kulman taakse ja vaimentua monesta tekijästä riippuen vähän tai kymmeniä desibelejä.

Ilmiöiden analyyttistä käsittelyä vaikeuttaa se, että käytännön tilanteissa esiintyy kaikkia edellä mainittuja - ja muitakin - ilmiöitä samanaikaisesti. Siksi ei useinkaan ole käytännöllistä yrittää ratkaista radiolinkin vaimennuksia laskennallisesti. Radiolaitteiden sijoittelua suunniteltaessa on kuitenkin hyvä olla tietoinen eri ilmiöistä sekä niiden mahdollisista suuruusluokista pahojen virheiden välttämiseksi.

\section{Radiolaitteiden ominaisuuksista}

Edellä esitettiin, että matalat radiotaajuudet vaimenevat vähemmän ja kulkevat pitemmälle. Miksei siis aina käytetä matalia taajuuksia? Eräissä sovelluksissa (esim. matkapuhelin - korvanappi) on tarkoituksenmukaista, että kaksi laitetta kommunikoi keskenään ilman että etäämmällä olevat laitteet häiriintyvät. Lisäksi pitkien aallonpituuksien laitteet ovat kookkaita. Vielä tärkeämpi seikka on se, että alhaisella taajuudella värähtelevään aaltoon voidaan sisällyttää vähemmän informaatiota kuin korkeataajuisempaan. Tämä johtuu informaation moduloimisesta radioaaltoon, jota on syytä selvittää ennen radiolaitteiden muiden ominaisuuksien käsittelyä.

\section{Modulaatiomenetelmiä}

Tunnetuin modulaatiomenetelmä lienee sähkötys, jossa radioaaltoa katkotaan rytmillä, joka vastaa sovittuja aakkosia. Samalle periaatteelle perustuu am-radio (amplitudimodulaatio), jossa radioaallon voimakkuutta huojutetaan samassa rytmissä kuin radion kaiutinelementin toivotaan huojuvan. Yleisradion nykyisin käyttämä $f m$ (taajuusmodulaatio) perustuu sen sijaan siihen, että esim. $100 \mathrm{MHz}$ taajuudella kuuluvan radiokanavan kantoaalto todellisuudessa huojuu joitain kymmeniä kilohertsejä keskitaajuuden ympärillä, ja tämä huojunta noudattaa halutun ääniaallon muotoa. Samalla kanava vaatii tietyn levyisen taajuuskaistan käyttöönsä (esim. \pm 20 kHz keskitaajuuden molemmin puolin), eikä aivan vierekkäisiä taajuuksia voida käyttää samanaikaisesti.

Digitaalista informaatiota voidaan moduloida kantoaaltoon pm (vaihemodulaatio, phase modulation) avulla. Tällöin lähetin aina sovitun ajanjakson välein kääntää kantoaallon vaiheen päinvastaiseksi ykkösen merkiksi, tai ei käännä nollan merkiksi. Eräs paljon käytetty fm- ja pm-menetelmien yhdistelmä on $f s k$ (frequency shifting key), jolloin signaali sovitussa rytmissä hyppii kahden (tai useamman) hyvin läheisen taajuuden välillä, esim. $869 \pm 0,025 \mathrm{MHz}$, jolloin yksi taajuus merkitsee 0:aa ja toinen 1:ä (Kuva 2). Kun viimeksi mainittuihin modulaatioihin lisätään mahdollisuus korottaa tai alentaa kantoaallon voimakkuutta am-radion tapaan, saadaan aikaiseksi tehokkaita koodausmenetelmiä, joiden jokaiseen tahdistettuun muutokseen saadaan jopa satoja mahdollisia muutosvaihtoehtoja. 


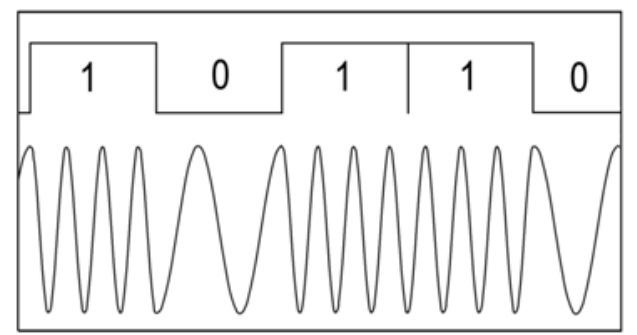

Kuva 2. Periaatekuva kahden taajuuden fsk-modulaatiosta.

Koska korkeataajuuksinen radioaalto värähtelee matalaa useammin, on selvää että edellä mainituilla modulointimenetelmillä voidaan kantoaaltoon koodata tietobittejä tiheämpään, ja radiokanavan tiedonsiirtokapasiteetti saadaan suureksi. Alhaisimpien ISM-taajuuksien tiedonsiirtokapasiteetit ovat tietoliikenteelle vaatimattomia, minkä lisäksi radioliikennemääräykset rajoittavat niiden jatkuvaa käyttöä esimerkiksi kieltämällä yksittäistä laitetta jatkuvasti tukkimasta kanavaa. Maatalouden mittaus- ja valvontalaitteiden tarpeisiin (pl. videokuvalaitteet) alhaiset taajuudet ovat silti houkuttelevimpia.

\section{Teho, herkkyys ja linkkibudjetti}

Lähettimen tärkein ominaisuus on lähetysteho, joka ilmoitetaan joko milliwattina (mW) tai sen desibelinä $(\mathrm{dBm})$. Pääosa ISM-taajuuksien kanavista on määräyksillä rajattu enimmäistehoille 1,10 tai $25 \mathrm{~mW}$ ja laitevalmistajat noudattavat näitä rajoituksia. Eräillä kanavilla sallitaan jopa $500 \mathrm{~mW}$ (+25 dBm) tehoiset lähettimet, kunhan toimintasuhde on alle $10 \%$ ajasta, mutta näiden kanavien käyttämiseen liittyy aina riski samanaikaisten lähettimien häiriöistä ja signaalin menettämisestä. Näihin kanaviin tuleekin turvautua vain sovelluksissa, joissa osan informaation menettäminen on hyväksyttävää tai radiosignaalin läpimeno voidaan varmistaa radiolaitteiden dialogilla.

Vastaanottimen tärkeimmät ominaisuudet ovat herkkyys ja signaali-kohina-suhde eli $s / n$. Herkkyydellä ilmoitetaan, kuinka heikon signaalin vastaanotin voi havaita. Tyypillinen digitaalisen vastaanottimen herkkyys on $-100 \mathrm{dBm}$ (eli $10^{-13} \mathrm{~W}$ ). Suuresta herkkyydestä ei ole hyötyä sellaisissa olosuhteissa, missä taustakohina on voimakasta. Tyypillinen kohinan teho asutusalueella on noin -90 $\mathrm{dBm}$, mutta saattaa ajoittain olla jopa $-70 \mathrm{dBm}$. Tällöin on selvää, että kohinaa heikompi signaali jää kohinan peittoon, eikä herkkäkään vastaanotin pysty signaalia havaitsemaan.

Taustakohinaa esiintyy jatkuvasti kaikilla taajuuksilla. Tästä syystä käytössä oleva modulaatiomenetelmä vaikuttaa kohinan määrään, sillä mitä leveämpää taajuuskaistaa esim. fm-kanava käyttää, sitä laajemmalta taajuuskaistalta joudutaan vastaanottamaan myös kohinaa. Vastaavasti radiojärjestelmä, joka käyttää mahdollisimman kapeaa kaistaa, mahdollistaa alhaisen kohinatehon vastaanottamisen. Kahdella hyvin lähekkäisellä taajuudella vaihtelevan fsk-kanavan kohina voi olla jopa alle $-110 \mathrm{dBm}$ ja demodulointi onnistuu kun signaali on muutamankin dB kohinaa voimakkaampi.

Kun tunnetaan lähettimen teho ja vastaanottimen herkkyys tai kohinateho, voidaan laskea linkkibudjetti, joka kertoo häipymävaran (esim. $+10 \mathrm{dBm}$ ja $-100 \mathrm{dBm}$, häipymävara $110 \mathrm{~dB}$ ). Vertaamalla häipymävaraa vapaan tilan vaimenemiseen (Taulukko 1) voidaan arvioida järjestelmän kantama hyvissä olosuhteissa.

\section{Antennin vire ja suuntaavuus}

Edellä on käsitelty vapaan tilan etenemistä ja lähetin-vastaanotinparia. Näiden lisäksi täytyy radiosignaalin tietenkin siirtyä lähettimeltä ilmaan ja jälleen ilmasta vastaanottimeen, mihin tarvitaan antennit. Edelleen, jos antenni ei ole kiinteä osa radiolaitetta, täytyy signaali johtaa laitteelta antennille johdinta tai kaapelia pitkin.

Lanka-antennin johdinta pitkin kulkeva vaihtosähkövirta synnyttää ympärilleen heikon sähkökentän. Kun lanka päättyy, virta kimpoaa takaisin johdinta pitkin synnyttäen jälleen ympärilleen kentän, kimpoaa taas toisesta päästä takaisin jne. Kun lanka on oikean pituinen suhteessa taajuutta vastaavan radioaallon pituuteen, muodostuu antennin ympärille seisova aaltoliike ja jokainen johtimessa kimpoava heijastus vahvistaa sähkökenttää johtimen ympärillä, minkä seurauksena antenni säteilee suurimman osan siihen johdetusta tehosta ympäristöönsä. Jos antennilanka ei ole oikean pituinen, eivät langan päistä heijastuvat aallot ole resonanssissa keskenään, muodostuu heikompi kenttä ja antenni säteilee vain osan sille johdetusta tehosta. Se osa tehosta, joka ei säteile antennista ulos, heijastuu ta- 
kaisin lähettimelle ja antennin hyötysuhde alenee. Antennin voidaan sanoa olevan vireessä silloin, kun $90 \%$ antennille johdetusta tehosta säteilee ja paluuvaimennus on $10 \%$.
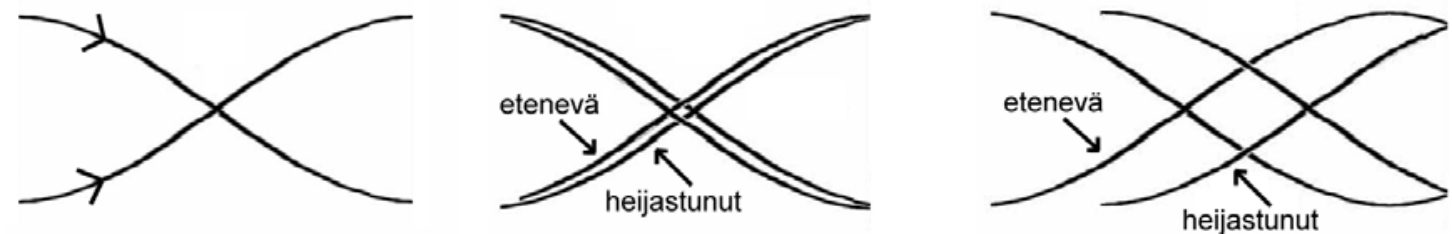

Kuva 3. Aalto heijastuu langan päästä joka on a) vireessä, b) lähes vireessä ja c) epävireessä.

Sähkömagneettinen kenttä muodostuu siis antennia ympäröivään väliaineeseen, ei antennilankaan. Jos antennin läheisyydessä on $\varepsilon_{r}$ :n suhteen poikkeavaa materiaalia (Taulukko 2), häiriintyy aallon resonanssi ja antennin hyötysuhde alenee tai jopa romahtaa. Kun esimerkiksi $870 \mathrm{MHz}: n$ aallonpituus ilmassa $\left(\varepsilon_{r}=1\right)$ on $35 \mathrm{~cm}$, on saman aallon pituus vedessä $\left(\varepsilon_{r}=80\right)$ vain $3,9 \mathrm{~cm}$ eli vedenalaisen antennilangan pituuden tulee olla $11 \%$ ilma-antenniin verrattuna. Jos antennin lähikentässä eli noin yhden aallonpituuden etäisyydellä säteilypisteestä sijaitsee eri materiaaleja, erityisesti kosteita, ei antennille ole yhtä oikeaa resonanssitaajuutta. Tästä syystä antennin lähikenttä tulee pitää vapaana joka suunnalta ja yhdelle taajuudelle tarkoitettua antennia ei pääsääntöisesti voi käyttää muulla taajuudella.

Se, että antennilla voidaan aikaansaada vahvistusta (engl. gain), perustuu antennin suuntaavuuteen. Itse säteilyteho ei voi lisääntyä antennissa ilman lisäenergiaa. Kun antenni säteilee sille johdettavan tehon vain yhteen suuntaan, on kentän tehontiheys tällä suunnalla suurempi ja vastaavasti päinvastaisella suunnalla heikompi. Kun tehoa ei lisätä, edellyttää vahvistus yhdellä suunnalla aina vaimennusta toisaalla. Näin ollen esimerkiksi suunta-antenni, jonka suuntakeilan leveys on $60^{\circ}$ antaa tälle suunnalle periaatteessa 36-kertaisen tehon (+15 dB) ympärisäteilevään antenniin nähden. Käytännössä suuntaavuus ei ole täydellistä ja vahvistus on geometristä tarkastelua vähäisempi. Myös suuntaava vastaanottoantenni, joka on suunnattu lähettimen suuntaan, antaa yhtä paljon vahvistusta, eikä vastaanota aaltoja muilta suunnilta.
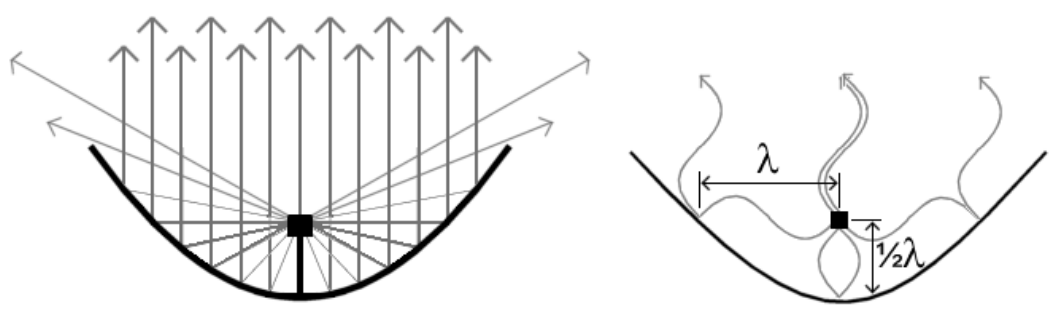

Kuva 4. Lautasantenni heijastaa osan ympärisäteilevän antennin säteistä yhdelle suunnalle. Oikein mitoitetun heijastimen kaikki aallot ovat samassa vaiheessa.

Antennin suuntaavuus perustuu yleisimmin joko heijastimeen tai suuntaelementteihin. Lisäksi on olemassa mm. paneeliantenneja, jotka rakenteestaan johtuen säteilevät tiettyyn suuntaan. Lautasantennin heijastin toimii samalla tavalla kuin heijastavat pinnat monitie-etenemisen tapauksessa. Kun säteilijä on sijoitettu täsmälleen puolen aallonpituuden etäisyydelle heijastavan lautasen pohjasta, ovat lautasen kautta heijastuneet aallot samassa vaiheessa kuin säteilijältä suoraan lähtevät, ja kaikki aallot muodostavat yhdessä voimakkaan summa-aallon. Suuntaavuus ilmoitetaan pääsääntöisesti antennin vahvistuksena pääsuunnassa, joka on usein luokkaa 5-20 dB. Usein vahvistuksen yksikkö kirjoitetaan $\mathrm{dBi}$, joka kertoo että vahvistus mitataan suhteessa isotrooppiseen eli täysin ympärisäteilevään antenniin, erotukseksi dipoliantennin suuntaavuuteen suhteutetusta yksiköstä $\mathrm{dBd}(2,15 \mathrm{dBi}=0 \mathrm{dBd})$. Oikein suunnatun antennin dBi-vahvistuksen voi suoraan summata aiemmin käsitellyn linkkibudjetin häipymävaraan.

\section{Johtimet ja vahvistimet}

Silloin, kun antenni ei ole rakenteellinen osa radiolaitetta, johdetaan aalto antennille johdinta pitkin. Korkeilla taajuuksilla johdin on yleensä koaksaalinen, eli kaapeli jossa on keskellä johdin, johtimen ympärillä tietynvahvuinen eriste ja uloimpana taas metallinen vaippa. Samalla tavalla kuin lankaantenni muodostaa ympärilleen sähkömagneettisen kentän, muodostuu koaksaalisessa johdossa kenttä johtimen ja vaipan välille. Radioaalto etenee siis johtimen ja vaipan välisessä eristekerroksessa eikä 
niinkään keskijohtimessa. Tästä syystä mikä tahansa epäjatkuvuus johtimessa (liitin, liitos, vaurio vaipassa, terävä taitos kaapelissa) sekoittaa johtimen rakenteen kohdaltaan, joka aiheuttaa häiriön johtimen impedanssissa. Osa aallon tehosta heijastuu takaisin epäjatkuvuuskohdasta ja etenevän aallon teho alenee.

Tyypillinen vaimennus ehjässä koaksaalijohdossa on $1,5-3 \mathrm{~dB} / \mathrm{m}$. Hyvän kontaktin ottavan liittimen, kuten kierteillä ruuvattavan sma- tai tnc-liittinparin vaimennus on noin $1 \mathrm{~dB}$, mutta heikkolaatuisen liittimen aiheuttama vaimennus voi nousta useisiin $\mathrm{dB}$ :hin, viallisten jopa kymmeniin. Tutkimuskäyttöön tulevissa laitteissa kannattaa poikkeuksetta turvautua täsmälleen oikeanpituiseksi valmistettuihin johtimiin, sillä laadukkaat mittatilausjohdot maksavat vain kymmeniä euroja (poislukien kalliit laboratoriotason johtimet). Mikäli mahdollista, radiolaite kannattaa sijoittaa antennin välittömään läheisyyteen (ei kuitenkaan lähikenttään) ja järjestää tarvittavat jatkojohdot radion tiedonsiirtoon ja virransyöttöön, ei antennijohtoon.

Radiolinkin kantaman kasvattamiseksi voidaan käyttää lähetysvahvistimia, mutta useimmiten laitevalmistajat ovat huomioineet radioliikennemääräykset jo valmistuksessa ja lähettimien lähetystehot ovat valmiiksi määräysten ylärajojen mukaiset. Heikon signaalin vastaanotossa ei kohtuuhintaisista vahvistimista juuri ole apua, sillä yleisesti ottaen vahvistimet lisäävät kohinaa ainakin yhtä paljon kuin itse signaalia, ja vaikka signaalin taso saataisiin nostettua vastaanottimen herkkyyden tasolle, pilaa pahentunut s/n signaalin käyttökelvottomaksi. Herkkä vastaanotin on parempi ratkaisu kuin vahvistin. Sen sijaan toistimilla voidaan parantaa järjestelmän kantavuutta. Toistin vastaanottaa signaalin, tulkitsee sen sisällön ja tuottaa uuden alkuperäistä lähetettä vastaavan radioaallon. WLANjärjestelmiin on saatavana hyvin edullisia toistimia, joita ketjuttamalla signaalia saadaan kuljetettua pitkiäkin matkoja. Muihin järjestelmiin haluttavat toistimet on yleensä tuotettava tapauskohtaisesti ja laitteen suunnittelu- ja valmistuskustannukset voivat nousta tuhansiin euroihin.

\section{Sovellusesimerkkejä}

Yleisesti käytetyt, standardoidut radiojärjestelmät soveltuvat usein huonosti maatilaolosuhteisiin. Tietokoneverkoille tarkoitettu WLAN on tiedonsiirtokapasiteetiltaan melko tehokas, mutta lähetystehot on rajattu niin alas, että käytännön yhteysetäisyydet rajoittuvat kymmeniin metreihin. Tarkkaan ottaen WLAN-suunta-antennien käyttö on kielletty, sillä antennin keilan suunnalla sallittu teho ylittyy.

Bluetooth ja RF-id ovat hyvin lähellä toisiaan sijaitsevien laitteiden liittämiseen tarkoitettuja protokollia, joiden kantama on van metrejä. Maatiloilla käytetään verrattaen paljon GSM-verkkoon pohjautuvia ratkaisuja, joissa käytännössä havaintolaitteessa on sisäänrakennettu matkapuhelin, joka tekstiviestinä tai GPRS-lähetteenä välittää tietoa tukiasemalle ja sieltä edelleen tietoverkkoon ja palvelimille. Tällöin tiedonsiirto on maksullista.

Helsingin yliopiston Agroteknologian laitoksella on kehitetty useita räätälöityjä langattomia mittauslaitteita, jotka pohjautuvat Nordic Semiconductorin nRF9E5-radiopiiriin. Piiri on muutaman millimetrin kokoinen ja muutaman euron hintainen mikroprosessori, jossa on sisäänrakennettu radiolähetin, joka pystyy tuottamaan enintään $10 \mathrm{~mW}(10 \mathrm{dBm})$ tehoisen radiosignaalin sekä $433 \mathrm{MHz}$ että $870 \mathrm{MHz}$ taajuudella ja FSK-modulaatiolla. Saman piirin vastaanottimen herkkyys on $-100 \mathrm{dBm}$.

Peltotiedustelija on $870 \mathrm{MHz}$ järjestelmä, jossa on maanalainen kosteutta ja lämpötilaa mittaava laite ja maanpäällinen vastaanotin. Järjestelmän haasteiksi osoittautuivat maanalaisen antennin toimivuus ja radioaallon heijastuminen pellon ja ilman rajapinnalta takaisin maan sisään. Lähetysteholla $+10 \mathrm{dBm}$ ja vastaanottimen herkkyydellä $-100 \mathrm{dBm}$ on häipymävara $110 \mathrm{~dB}$. $25 \mathrm{~cm}$ maakerros vaimentaa signaalia noin 20-50 dB, joten ilmatien häipymäravaksi jää $90-60 \mathrm{dBm}$ ja siis kantamaksi ilmassa 800-25 m (Taulukko 1). Kantaman alaraja on liian lyhyt pellon langattomaan seurantaan, joten vastaanottimeen kytkettiin aluksi $+9 \mathrm{~dB}$ vahvistava paneeliantenni, joka sittemmin korvattiin $+21 \mathrm{~dB}$ vahvistavalla lautasantennilla, jonka keila on enää vain $12^{\circ}$. Näin saatiin häipymävara $131 \mathrm{~dB}$ eli maakerroksen vaimennuksen jälkeen vähimmäiskantama $300 \mathrm{~m}$, mutta kaikki järjestelmän peltotiedustelijat on käytännössä sijoitettava yhdelle linjalle, jotta ne ovat lautasantennin kapeassa keilassa. Myös lähellä antennia olevista tiedustelijoista keila "ampuu yli”. Lähettimiin ollaan kehittämässä lähetysvahvistinta, joka nostaa lähetystehoksi $+20 \mathrm{dBm}$, jotta kantamaa voidaan pidentää lautasantennilla tai vaihtoehtoisesti saavuttaa sama kantama leveämmän keilan (alhaisemman vahvistuksen) antennilla. Koska vastaanotin itsessään on hyvin edullinen laite, tullaan jatkossa käyttämään kahta antennia, joista 
kumpikin varustetaan omalla vastaanottimellaan. Tiedonkeruu toteutetaan yhdellä tietokoneella, joka tallentaa kummankin vastaanottimen tiedot.

Langattomalla kiihtyvyysanturilla voidaan seurata lehmän liikkeitä ja sopivien laskennallisten menetelmien kautta havainnoida muutoksia eläinten käytöksessä, mikä puolestaan indikoi muutoksia eläimen hyvinvoinnissa. Navetta on tiedonsiirtoetäisyyksien puolesta niin pieni, että kaikki rakennuksen sisältä tulevat $870 \mathrm{MHz}$ signaalit saadaan vastaanotettua yhdellä tai kahdella navettaan suunnatulla ja nurkkaan sijoitetulla paneeliantennilla. $433 \mathrm{MHz}$ olisi vielä käytettyä taajuutta kantavampi navetassa, mutta lähettimien antennien kaksinkertainen fyysinen koko saattaisi muodostua laitteita kantavien eläinten kannalta vaikeaksi. Aiheesta on käynnissä väitöstutkimus. Monitie-etenemisen ansiosta radiolaitteiden välillä ei tarvita näköyhteyttä, sillä heijastavia pintoja on paljon. Toistimen toteuttaminen navetassa on helppoa, sillä toistimelle voidaan järjestää käyttöjännite vaivattomasti, mutta signaalien toisto helposti tukkii rajallisen radiokanavan. $2400 \mathrm{MHz}$ laitteilla navettaan muodostuu helposti kuolleita pisteitä, sillä esim. väliseinä vaimentaa korkeaa taajuutta voimakkaasti, ja toisaalta heijastusreitti saattaa muodostua näin korkeataajuiselle signaalille liian pitkäksi (Taulukko 1). Suuren karjan seurannan haasteeksi muodostuu lähettimien aikaerottelu, sillä päällekkäin tapahtuvat lähetykset sotkevat yleensä molemmat signaalit. Tästä syystä lähettimet on jaettava eri taajuuskaistoille (esim. 869,2 MHz, 869,4 MHz ja 869,6 MHz). Tällöin on käytettävä myös yhtä montaa vastaanotinta ja kullekin omaa antennia. Kiihtyvyysmittausaineisto on käsittelemättömänä raskasta, joten radiokanavan riittävyyden kannalta on anturien hyvä tehdä jonkinasteista analyysiä aineistosta, ja lähettää radioteitse ainoastaan johtopäätösten kannalta välttämättömät tiedot.

\section{Kirjallisuus}

Lindell, I. 2000. Radioaaltojen eteneminen. Otatieto, Espoo

Nordic Semiconductor. 2009. nRF9E5 Multiband Transceiver/MCU/ADC. http://nordicsemi.no

Pastell, M., Tiusanen, J., Hakojarvi, M., \& Hänninen, L. 2009. A wireless accelerometer system with wavelet analysis for assessing lameness in cattle. Biosystems Engineering 104(4): 545-551

Räisänen, A. \& Lehto, A. 2007. Radiotekniikan perusteet. Otatieto, Espoo

Tiusanen, J. 2007. Langattoman peltotiedustelijan toimintaympäristö ja laitesuunnittelu. MMTEKJulkaisuja 26. Väitöskirja, Helsingin yliopisto

Tiusanen, J. 2008. Wireless Soil Scout prototype radio signal reception compared to the attenuation model. Precision Agriculture 10(5): 372-381

Tiusanen, J., Pastell, M. \& Hänninen L. 2008. Reducing wireless acceleration data flow by intelligent embedded algorithms. NJF seminar 411 (Espoo)

Viestintävirasto. 2006. 15W/2006 M. Määräys luvasta vapaiden radiolähettimien yhteistaajuuksista ja käytöstä. http://www.ficora.fi 